\title{
SOME FACTORS AFFECTING ENZYME RELEASE FROM CEREBRAL LYSOSOMES : INHIBITORY EFFECTS OF LEAD
}

\author{
Kazuo NAKAGAWA, Masukichiro ASAMI and Kinya KURIYAMA* \\ Hygiene Laboratory, Department of Food Science, \\ Kyoto Woman's University, Higashiyama-ku, Kyoto 605. Japan, \\ *Department of Pharmacology. Kyoto Prefectural University of Medicine. \\ Kamikyo-ku, Kyoto 602, Japan \\ Accepted July 31, 1982
}

\begin{abstract}
The mode of the inhibitory effect of lead ion on the release of enzymes from cerebral lysosomes isolated from young Wistar rats was examined. The incubation of cerebral lysosomes in a low pH medium or with adenosine triphosphate $(1 \mathrm{mM})$ at neutral $\mathrm{pH}$ resulted in the decrease of the release of acid phosphatase (EC 3.1.3.2) and $\beta-\mathrm{N}$ acetylglucosaminidase (EC 3.2.1.30) activities. Multivalent cations such as $\mathrm{Mn}^{2+}$. $\mathrm{Co}^{2+}$ and $\mathrm{La}^{3+}$ inhibited the enzyme release, while $\mathrm{Ca}^{2+}$ facilitated the release. On the other hand, lead ion suppressed the $\mathrm{Ca}^{2+}$-induced enzyme release, but this suppressive effect of lead ion was eliminated by the treatment of lysosomes with phospholipase $C$ and phospholipase $A_{2}$. These results suggest that lead ion may alter the ionic permeability of cerebral lysosomal membrane by reacting with membraneous phospholipids, and thus may prevent the release of lysosomal enzymes in vitro.
\end{abstract}

The pathogenesis of neurological disorders associated with lead poisoning seems to be one of the important problems which should be clarified urgently. The neurotoxic effects of lead, however, has not been well understood. although various neurochemical or morphological studies have been employed on this disease (1-4). In a previous report (5), we have indicated that the accumulation of lead in the brain is larger in young animals than in adult animals, and the release of cerebral lysosomal enzymes in vitro is inhibited by lead acetate. The present study has been carried out to determine the mechanism of action of the inhibitory effect of lead ion on the release of cerebral lysosomal enzymes. Some factors affecting the enzyme release were also examined.

\section{Materials and Methods}

Male young rats (Wistar strain) weighing 50-60 g were used in all experiments. After the decapitation, the brains were quickly removed and homogenized in cold $0.44 \mathrm{M}$ sucrose with a Teflon glass homogenizer. Lysosomes from the brain homogenate were prepared as described previously (5). Isolated lysosomes were resuspended in $0.44 \mathrm{M}$ sucrose- $0.177 \mathrm{M} \mathrm{KCl}$ solution. The release of lysosomal enzymes was determined as follows: the lysosomal suspension $(1.5 \mathrm{ml})$ was incubated with each test compound and $10 \mathrm{mM}$ Tris- $\mathrm{HCl}$ buffer $(\mathrm{pH} 7.1)$ in a final volume of $2.0 \mathrm{ml}$ at $37^{\circ} \mathrm{C}$ for $15 \mathrm{~min}$, except otherwise described. When total enzyme activity in the lysosomes was determined, $0.1 \%$ Triton $X-100$ was added in the incubation medium. After cooling in ice-water. each reaction mixture was centrifuged at $13,000 \times \mathrm{g}$ for $10 \mathrm{~min}$, and 0.3 and $0.5 \mathrm{ml}$ of the resultant supernatant were used to determine the activities of acid phosphatase (EC 3.1.3.2) and $\beta$ - $N$-acetylglucosaminidase (EC 3.2.1.30), respectively. 
Acid phosphatase and $\beta-N$-acetylglucosaminidase activities were measured spectrophotometrically according to the methods of Barrett and Heath (6) as indicated in our previous report (5). The magnitude of the enzyme release was shown as the percentage of the control or the percentage of total enzyme activity.

Significance of the results was analyzed by the Student's paired $t$-test, and the differences having $P<0.05$ were considered to be statistically significant.

Materials: $\quad$ P-Nitrophenyl-N-acetyl-Dglucosaminide, adenosine triphosphate (ATP) adenosine diphosphate (ADP), adenosine monophosphate (AMP), phospholipase $A_{2}$ (porcine pancreas), phospholipase $\mathrm{C}(\mathrm{Cl}$. welchii), glutathione, dithiothreitol and $\mathrm{N}$ ethylmaleimide were purchased from the Sigma Chemical Co. (Saint Louis, Mo, U.S.A.). Other chemicals used were guaranteed grade and obtained from Nakarai Chemicals, Ltd. (Kyoto, Japan).

\section{Results}

Extralysosomal $\mathrm{pH}$ and the release of enzymes: It is probable that the $\mathrm{pH}$ gradient across the lysosomal membrane is maintained in living cells since most of the lysosomal enzymes have acidic $\mathrm{pH}$ optimums. Therefore. lysosomal particles were incubated with $5 \mathrm{mM}$ Tris maleate buffer having various $\mathrm{pH}$ values

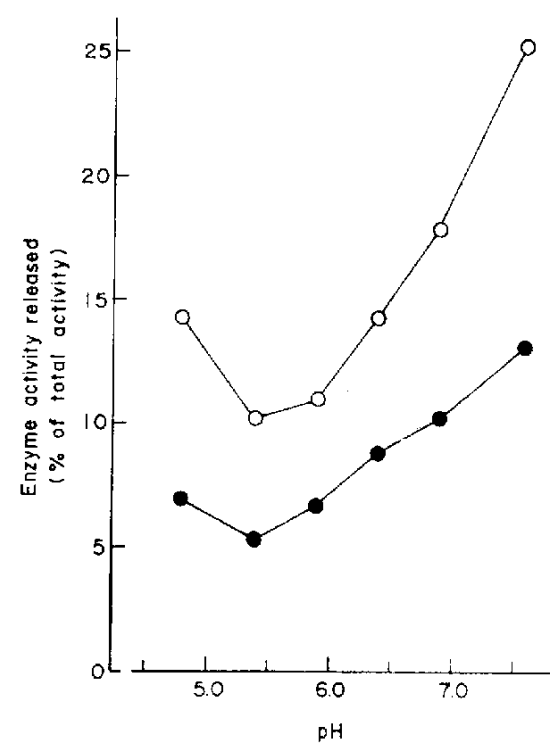

Fig. 1. Relationship between extralysosomal pH and the release of lysosomal enzymes. Cerebral lysosomes were incubated in the medium buffered with $5 \mathrm{mM}$ Tris maleate described in the text. Enzyme activity released was indicated as the percentage of total activity which was determined after solubilizing with $0.1 \%$ Triton $X-100$. Open and closed circles represent $\hat{\beta}-\mathrm{N}$-acetylglucosaminidase and acid phosphatase activities, respectively. Each point is the mean of two separate experiments.

Table 1. Effect of adenine nucleotides on release of lysosomal enzymes

\begin{tabular}{lcccc}
\hline & \multicolumn{3}{c}{ Enzyme activity $(\%$ of control $) \pm S . E}$. \\
\cline { 3 - 3 } & & Released $\left(E_{1}\right)$ & Total $\left(E_{2}\right)^{* *}$ & $\left(E_{1} / E_{2}\right) \times 100$ \\
\hline Control & 100 & 100 & 100 \\
ATP (1 mM) & AP & $61 \pm 3$ & $107 \pm 2$ & $57 \pm 2^{* * *}$ \\
& AG & $65 \pm 3$ & $99 \pm 2$ & $66 \pm 2^{* * *}$ \\
ADP (1 mM) & AP & $82 \pm 9$ & $104 \pm 6$ & $78 \pm 6^{*}$ \\
& AG & $86 \pm 4$ & $100 \pm 2$ & $86 \pm 4^{*}$ \\
AMP (1 mM) & AP & $97 \pm 11$ & $95 \pm 7$ & $103 \pm 12$ \\
& AG & $100 \pm 1$ & $99 \pm 1$ & $102 \pm 2$ \\
\hline
\end{tabular}

Cerobral lysosomes were incubated with each test compound in the presence $\left(E_{2}\right)$ or absence $\left(E_{1}\right)$ of $0.1 \%$ Triton X-100. After centrifugation, enzyme activity in the resultant supernatant was measured. Each value indicates the mean $\pm S$.E. obtained from four separate experiments. "Determined in the presence of $0.1 \%$ Triton $X-100$. ${ }^{* *} P<0.01$ and ${ }^{*} P<0.05$, compared with each control value. Abbreviations used: AP. Acid phosphatase: AG, $\beta$-N-Acetylglucosaminidase. 
Table 2. Effect of metallic cations on release of lysosomal enzymes

\begin{tabular}{|c|c|c|c|}
\hline \multirow{2}{*}{\multicolumn{2}{|c|}{ Cations }} & \multicolumn{2}{|c|}{ Enzyme activity released ( $\%$ of control) $\pm S . E$. } \\
\hline & & $A P$ & $A G$ \\
\hline \multicolumn{2}{|c|}{ Control } & 100 & 100 \\
\hline $\mathrm{Ba}^{2+}$ & $(1 \mathrm{mM})$ & $81 \pm 8$ & $83 \pm 6$ \\
\hline $\mathrm{Mg}^{2+}$ & $(1 \mathrm{mM})$ & $83=8$ & $84 \pm 3^{* *}$ \\
\hline $\mathrm{Mn}^{2+}$ & $(1 \mathrm{mM})$ & $55 \pm 6^{* * *}$ & $73 \pm 1^{* * *}$ \\
\hline $\mathrm{CO}^{2+}$ & $(1 \mathrm{mM})$ & $50 \pm 10^{* *}$ & $60 \pm 4^{* * *}$ \\
\hline $\mathrm{La}^{3 \div}$ & $(1 \mathrm{mM})$ & $50 \pm 15^{*}$ & $40 \pm 11^{*}$ \\
\hline
\end{tabular}

Enzyme activity appearing in the supernatant was determined as described in the text. The mean \pm S.E. obtained from four experiments is shown. ${ }^{* *} P<0.01,{ }^{* *} P<0.02$. ${ }^{*} P<0.05$. compared with each control value. Abbreviations used: A. Acid phosphatase: AG, $\beta$-N-Acetylglucosaminidase.

adjusted by $\mathrm{NaOH}$ solution. The release of acid phosphatase and $\beta-N$-acetylglucosaminidase decreased in para!lel with the decrease of extralysosomal $\mathrm{pH}$, and it showed a minimum at $\mathrm{pH} 5.4$ (Fig. 1).

Effect of adenine nucleotides on the release of enzymes: The addition of ATP inhibited the lysosomal release of both enzymes without directly affecting the activity of each enzyme. ADP was less effective than ATP on the release of the enzymes, and AMP was found to be ineffective for preventing the release of both enzymes (Table 1).

Effect of metallic cations on the release of enzymes: Table 2 shows the effect of metallic cations, which were added as chloride salts, on the release of lysosomal enzymes. $\mathrm{Ba}^{2+}$ poorly inhibited the release of both enzymes, and $\mathrm{Mg}^{2+}$ slightly inhibited the release. On the other hand. $\mathrm{Mn}^{2+}, \mathrm{Co}^{2+}$ and $\mathrm{La}^{3+}$ drastically inhibited the release of both enzymes from cerebral lysosomes. These cations, however, did not interfere with the assay of both enzyme activities (data not shown)

Interaction between $\mathrm{Pb}^{2+}$ and $\mathrm{Ca}^{2+}$ on the release of lysosomal enzymes: Calcium is well known to play important roles in various cell functions, for example, in the release of neurotransmitters (7). In addition, calciumlead interaction in neuronal tissues has been demonstrated (2, 8-10). The addition of

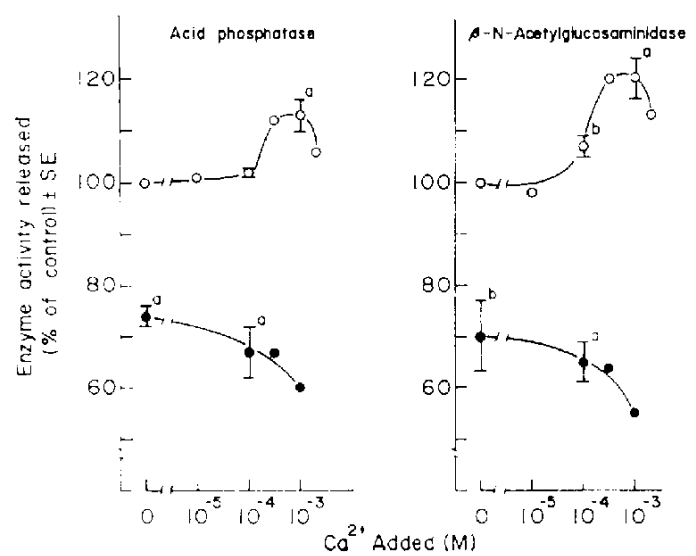

Fig. 2. Effect of lead acetate on calcium-induced release of lysosoma! enzymes. Cercbral lysosomes were incubated with various concentrations of $\mathrm{CaCl}_{2}$ alone (open circle) or with $\mathrm{CaCl}_{2}$ and lead acetate $\left(10^{-4} \mathrm{M}\right)$ (closed circle). The extent of the enzymo relcasc was expressed as percentage of the control value which was determined in the absence of $\mathrm{Ca}^{2+}$ and $\mathrm{Pb}^{2+}$. Each point represents the mean of two separate experiments or the mean $\pm S$. E. obtained from four separate experiments. : $P<0.01$, ${ }^{b} P<0.05$, compared with each control value.

$10^{-4}-10^{-3} \mathrm{M}$ calcium significantly stimulated the release of both acid phosphatase and $\beta$-N-acetyiglucosaminidase activities. The calcium-induced enzyme releases, however, disappeared completely in the presence of $0.1 \mathrm{mM}$ lead acetate (Fig. 2).

Effect of sulfhydryl compounds on the release of lysosomal enzymes: Since Van Caneghem (11) has shown that sulfhydryl 
compounds stabilize the hepatic lysosomes of the rat, we have also examined the effect of sulfhydryl compounds on the release of enzymes from cercbral lysosomes (Table 3) The total activity of acid phosphatase was increased 2 or 3 -fold by the addition of reduced glutathione or dithiothreitol, whereas $\beta-N$-acetylglucosaminidase activity remained unchanged. When the ratio of apparent activity released $\left(E_{1}\right)$ to total activity $\left(E_{2}\right)$ was calculated, it became clear that the amount of enzymes released was diminished by the addition of reduced glutathione. $\mathrm{N}$-ethylmaleimide or dithiothreitol. Oxidized glutathione slightly inhibited the release of acid phosphatase. On the other hand, reduced glutathione alone significantly inhibited the release of $\beta-N$-acetylglucosaminidase. Dithiothreitol also had a tendency to inhibit the enzyme release. These results strongly suggest that the reduction of $\mathrm{SH}$ groups in the Iysosomal membrane may suppress the release of lysosomal enzymes

$\mathrm{Pb}^{2+}\left(10^{-4} \mathrm{M}\right)$, as reported previously. prevented the Iysosomal releases of acid phosphatase and $B-N$-acetylglucosaminidase without having an affect on the enzyme activities. The addition of an equimolar concentration of a thiol compound with $\mathrm{Pb}^{2+}$ hardly modified the preventative effect of $\mathrm{Pb}^{2+}$.

Interaction between $\mathrm{Pb}$ and phospholipase on the release of lysosomal enzymes: The addition of phospholipase $C$ or phospholipase $A_{2}$ increased the release of both lysosomal enzymes. Acid phosphatase was more sensitive to the addition of phospholipases than $\beta-N$-acetylglucosaminidase. Furthermore, the

Table 3. Effect of sulfhydryl compounds on release of lysosomal enzymes

\begin{tabular}{|c|c|c|c|c|c|}
\hline & & & \multicolumn{3}{|c|}{ Enzyme activity (\% of control) $=5 . E$. } \\
\hline & & 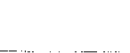 & Relcased $\left(E_{1}\right)$ & Total $\left(\mathrm{E}_{2}\right)^{\#}$ & $\left(E_{1} / E_{2}\right) \times 100$ \\
\hline \multicolumn{3}{|l|}{ Control } & 100 & 100 & 100 \\
\hline \multirow[t]{2}{*}{ GSH } & $(1 \mathrm{mM})$ & $A P$ & $117 \pm 4$ & $282 \pm 10$ & $57=3^{* *}$ \\
\hline & & $A G$ & $85 \pm 4$ & $102 \pm 2$ & $83=4^{*}$ \\
\hline \multirow[t]{2}{*}{ GSSG } & $(1 \mathrm{mM})$ & $A P$ & $108 \pm 14$ & $155 \pm 7$ & $70=10$ \\
\hline & & $A G$ & $99 \pm 2$ & $99+2$ & $101 \pm 4$ \\
\hline \multirow[t]{2}{*}{ NEM } & $(1 \mathrm{mM})$ & $A P$ & $93 \pm 5$ & $125 \pm 9$ & $76 \pm 7^{*}$ \\
\hline & & $A G$ & $109 \div 2$ & $101 \pm 2$ & $108 \pm 4$ \\
\hline \multirow[t]{2}{*}{ DTT } & $(1 \mathrm{mM})$ & $A P$ & $91 \pm 13$ & $204 \pm 14$ & $44 \pm 4^{* * *}$ \\
\hline & & $A G$ & $82=5$ & $91 \pm 3$ & $91 \pm 7$ \\
\hline \multirow[t]{2}{*}{$\mathrm{Pb}^{2+}$} & $(0.1 \mathrm{mM})$ & $A P$ & $68 \pm 5$ & $98 \pm 4$ & $69 \pm 6^{*}$ \\
\hline & & $A G$ & $88 \pm 2$ & $100 \pm 1$ & $88 \pm 1^{* *+}$ \\
\hline$\left\{\begin{array}{c}\mathrm{Pb}^{2+} \\
+\end{array}\right.$ & $(0.1 \mathrm{mM})$ & AP & $62 \pm 5$ & $104 \pm 7$ & $60 \pm 8^{*}$ \\
\hline $\mathrm{IGSH}$ & $(0.1 \mathrm{mM})$ & $A G$ & $84 \pm 4$ & $101 \pm 2$ & $83 \pm 3^{* *}$ \\
\hline$\left\{\begin{array}{c}\mathrm{Pb}^{2+} \\
+\end{array}\right.$ & $(0.1 \mathrm{mM})$ & A.P & $63 \pm 5$ & $98 \pm 5$ & $65 \pm 8^{*}$ \\
\hline GSSG & $(0.1 \mathrm{mM})$ & $A G$ & $87+3$ & $101 \pm 2$ & $86 \pm 2^{* * *}$ \\
\hline$\left\{\begin{array}{c}\mathrm{Pb}^{21} \\
+\end{array}\right.$ & $(0.1 \mathrm{mM})$ & $A P$ & $84 \pm 3$ & $127 \pm 9$ & $67 \pm 4^{* *}$ \\
\hline IDTT & $(0.1 \mathrm{mM})$ & $A G$ & $89+2$ & $98 \pm 1$ & $92 \pm 3$ \\
\hline
\end{tabular}

Enzyme activity was measured as described in the text and footnote of Table 1 . The meantS.E. from three or four separate experiments are shown. \#Determined in the presence of $0.1 \%$ Triton $X-100$. **P<0.01, "*P<0.02, "P<0.05, compared with each control value. Abbreviations used: GSH, Reduced glutathione: GSSG. Oxidized glutathione: NEM, N-Ethylmaleimide: DTT. Dithiothreitol: AP. Acid phosphatase: $A G, \beta-N$-Acetylglucosaminidase. 


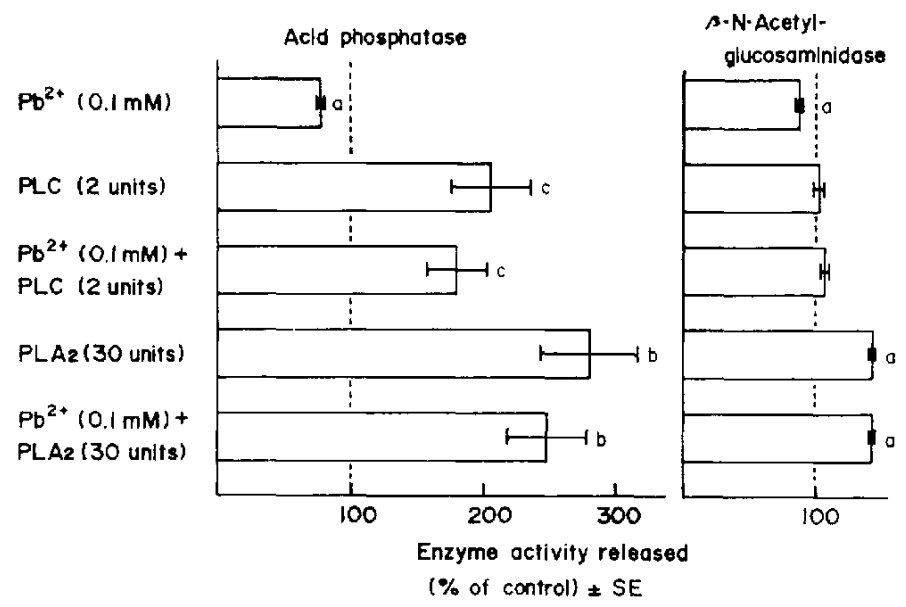

Fig. 3. Interaction between lead and phospholipases on the release of Iysosomal enzymes. Each value indicates the mean $\pm S$.E. obtained from four separate experimonts. a $P<0.01, b P<0.02, c P<0.05$. compared with each control value which was determined in the absence of lead ion and phospholipases.

Abbreviations used; PLC, phospholipase $C$; PLA , phospholipase $A_{2}$.

addition of both phospholipases eliminated the $\mathrm{Pb}$-induced inhibition (Fig. 3).

\section{Discussion}

Intralysosomal pH is thought to be more acidic than extralysosomal $\mathrm{pH}$ in living cells (12, 13). Two mechanisms which maintain such a low pH in the inside of lysosomes have been postulated: one of these hypotheses is that a low intralysosomal $\mathrm{pH}$ is the consequence of a Donnan equilibrium resulting from the non-diffusible anions inside of the Iysosomes and the selective permeability of the membrane to cations (14), and the other hypothesis is that an ATP-dependent proton pump which is linked to ATPase activity is present in the Iysosomal membrane (15-17). On the other hand, it has been reported that the internal $\mathrm{pH}$ of secondary lysosomes isolated from the liver is strongly influenced by the $\mathrm{pH}$ of the surrounding medium: the intralysosomal $\mathrm{pH}$ increases as the external $\mathrm{pH}$ is raised, especially when a high concentration of potassium ion is added into the medium $(14,18)$.

If the above findings are applicable to brain lysosomes, the decrease in the release of enzymes with the fall of extralysosomal $\mathrm{pH}$ found in the present study may be attributed to the changes in the intralysosomal $\mathrm{pH}$. This explanation may be further supported by the fact that the addition of ATP attenuates the release of enzymes, since ATP is known as an agent which lowers the intralysosomal $\mathrm{pH}$ in vitro probably due to the stimulation of the ATP-dependent proton pump (17). Although the exact reason why a low intralysosomal $\mathrm{pH}$ prevents the enzyme release is unknown at present, it may possible that the dissociation of enzymes from the binding sites may be facilitated under these conditions. In fact, it has been reported that acidification of lysosomes induces the dissociation of bound enzymes from receptors $(19,20)$. In addition, Gonzalez-Noriega et al. (21) showed that chloroquine, which increases intralysosomal $\mathrm{pH}$, enhanced the secretion of lysosomal enzymes and inhibited enzyme pinocytosis in human fibroblast.

Henning (14) indicated that metallic cation-proton exchange across the lysosomal membrane decreased with the decrease of atomic weight and with increasing charge of the cation. Furthermore, he showed that 
the difference in the rate of metallic cationproton exchange was due to the difference in the size of hydrated cation. In the present study, we have also found that metal ions, except for $\mathrm{Ca}^{2+}$, inhibited the release of Iysosomal enzymes. Considering these facts, we are attempting to postulate that the inhibitory effect of lead ion on the release of Iysosomal enzymes may correlate with the dissociation of lysosomal enzymes from binding sites within lysosomes which are endowed with denatured potassium-proton exchange by $\mathrm{Pb}^{2+}$. Since we incubated the Iysosomal particles in the medium containing a high concentration of potassium at $\mathrm{pH} 7.1$. the hindrance of potassium-proton exchange in the lysosomes treated with $\mathrm{Pb}^{2+}$ might result in a lower $\mathrm{pH}$ within the lysosomes than that in the control.

One of the important findings obtained in this study is that calcium ion alone stimulates the release of lysosomal enzymes, but $\mathrm{Pb}$ ion eliminates the calcium-induced release. Considering the fact that $\mathrm{Ca}^{2+}$ did not alter the intralysosomal $\mathrm{pH}$ (14), the facilitation of Iysosomal enzyme release by calcium ion may be attributed to different mechanisms from the $\mathrm{pH}$ shift within Iysosomes. One possible interpretation may be that an interaction between endogenous $\mathrm{Ca}^{2+}$ and added $\mathrm{Pb}^{2+}$ is present and contributes to the inhibitory effect of lead, but it remains to be tested in further studies

In the present study, it has been also found that thiol compounds are able to stabilize cerebral lysosomal membranes as Van Caneghem (11) indicated in liver lysosomes. It is uncertain, however, whether or not $\mathrm{Pb}$ ion prevents the release of lysosomal enzymes by reacting with $\mathrm{SH}$ groups in lysosomal membranes since oxidized glutathione and alkylating agents such as $N$-ethylmaleimide inhibited the release of acid phosphatase alone, probably reacting with a sulfhydryl moiety in the enzyme molecule $(22,23)$.
Furthermore, the addition of equimolar concentration of $\mathrm{SH}$ compounds with $\mathrm{Pb}^{2+}$ did not modify the $\mathrm{Pb}$-induced alteration. We have concluded, therefore, that the interaction of $\mathrm{Pb}^{2+}$ with $\mathrm{SH}$ moieties in the Iysosomal membrane may not be an essential factor involved in the inhibitory effect of $\mathrm{Pb}$ ion.

The inhibitory effect of $\mathrm{Pb}$ on lysosomal enzyme release disappeared when exogenous phospholipases were added. This result suggests that the action of $\mathrm{Pb}$ ion may be due to the interaction of $\mathrm{Pb}^{2+}$ with membrane components such as phospholipids, which are known to be involved in the maintenance of permeability of the lysosomal membrane (24). In mammalian brains, phospholipids are known to be broken down by various kinds of phospholipases which have different $\mathrm{pH}$ optimums, different sensitivity to $\mathrm{Ca}^{2+}$, and different subcellular distribution (25-29). Exact molecular mechanisms underlying the interaction between $\mathrm{Pb}^{2+}$ and Iysosomal membranous phospholipids, however, remain to be examined.

Acknowledgement: We are grateful to Misses Kaori Ikeda and Tomoko Suzuki for their skillful technical assistance.

\section{References}

1) Shin, T.-M. and Hanin, I.: Chronic lead exposure in immature anima!s: Neurochemical correlates. Life Sci. 23, 877-888 (1978)

2) Silbergeld. E.K. and Adler, H.S.: Subcellular mechanisms of lead neurotoxicity. Brain Res. 148, 451-467 (1978)

3) Dyck, P.J., Windebank, A.J., Low, P.A. and Baumann, W.J.: Blocd nerve barrier in rat and cellular mechanisms of lead-induced segmental demyelination. J. Nouropathol. Exp. Neurol. 39, 700-709 (1980)

4) Toews, A.D., Krigman, M.R., Thomas, D.J. and Morell, P.: Effect of inorganic lead exposure on myelination in the rat. Neurochem. Res. 5, 605$616(1980)$

5) Nakagawa, K., Asami, M. and Kuriyama, K.: inhibition of relcase of lysosomal enzymes in young rat brain by lead acetate. Toxicol. Appl. 
Pharmacol. 56, 86-92 (1980)

6) Barrett, A.J. and Heath, M.F.: Lysosomal enzymes. In Lysosomes-A Laboratory Handbook, Edited by Dingle, J.T., p. 19-145. Elsevier/North-Holland, Amsterdam (1977)

7) Katz, B. and Miledi, R.: Ionic requirements of synaptic transmitter release. Nature 215, 651 (1967)

8) Kober, T.E. and Cooper, G.P.: Lead competitively inhibits calcium-dependent synaptic transmission in the bullfrog sympathetic ganglion. Nature 262, 704-705 (1976)

9) Goldstein, G.W.: Lead encephalopathy: the significance of lead inhibition of calcium uptake by brain mitochondria. Brain Res. 136, $185-$ 188 (1977)

10) Kim, C.S., O'Tuama, L.A., Cookson, S.L. and Mann, J.D.: The effects of lead poisoning on calcium transport by brain in 30-day-old albino rabbits. Toxicol. Appl. Pharmacol. 52, 491-496 (1980)

11) Van Caneghem, P.: Influence of substances with thiol functions and their reagents on the fragility of lysosomes. Biochem. Pharmacol. 21, 2417-2424 (1972)

12) Coffey, J.W. and de Duve, C.: Digestive activity of lysosomes. J. Biol. Chem. 243, 3255-3263 (1968)

13) Ohkuma, S. and Poole, B.: Fluorescence probe measurement of intralysosomal $\mathrm{pH}$ in living cells and the perturbation of $\mathrm{pH}$ by various agents. Proc. Natl. Acad. Sci. U.S.A. 75, 3327-3331 (1978)

14) Henning, $\mathrm{R}$ : $\mathrm{pH}$ gradient across the lysosomal membrane generated by selective cation permeability and Donnan equiribrium. Biochim. Biophys. Acta 401, 307-316 (1975)

15) Mego, J.L., Farb, R.M. and Barnes, J.: An adenosine triphosphate-dependent stabilization of proteolytic activity in hetcrolysosomes. Biochem. J. 128, 763-769 (1972)

16) Chung, C.H., Elliott, R.L. and Mego, J.L.: Lysosomal membrane adenosine triphosphatase; solubilization and partial characterization. Arch. Biochem. Biophys. 203, 251-259 (1980)

17) Schneider, D.L.: ATP-dependent acidification of intact and disrupted lysosomes. J. Biol. Chem. $256,3858-3864$ (1981)
18) Reijngoud, D.L. and Tager, J.M.: Measurement of intralysosomal $\mathrm{pH}$. Biochim. Biophys. Acta 297, 174-178 (1973)

19) Fischer, H.D., Gonzalez-Noriega, A. and Sly, W.S.: $\beta$-Glucuronidase binding to human fibroblast membrane receptors. J. Biol. Chem. 255, 5069-5074 (1980a)

20) Fischer, H.D., Gonzalez-Noriega, A., Sly, W.S. and Morré, D.J.: Phosphomannosyl-enzyme receptors in rat liver. J. Biol. Chem. 255, 96089615 (1980b)

21) Gonzalez-Noriega, A., Grubb, J.H., Talkad, V. and Sly, W.S.: Chloroquine inhibits lysosomal enzyme pinocytosis and enhances lysosomal enzyme secretion by imparing receptor recycling. J. Cell Biol. 85, 839-852 (1980)

22) Abul-Fadl, M.A.M. and King, E.J.: Properties of the acid phosphatase of erythrocytes and of the human prostate gland. Biochem. J. 45, 51-60 (1949)

23) Macdonald, K.: The hydrolysis of phenyt phosphate by mouse-liver acid phosphatase. Biochem. J. 80, 154-161 (1961)

24) Szabo, G.: Mechanisms by which small molecules alter ionic permeability through lipid bilayer membranes. In Membrane Toxicity, Edited by Miller, M.W. and Shamoo. A.E., p. 167-190. Plenum Press, New York (1977)

25) Thompson. W.: The hydrolysis of monophosphoinositide by extracts of brain. Can. J. Biochem. 45, 853-861 (1967)

26) Copper, M.F. and Webster, G.R.: The differentiation of phospholipase $A_{1}$ and $A_{2}$ in rat and human nervous tissues. J. Neurochem. 17. $1543-1554$ (1970)

27) Lapetina, E.G. and Michell, R.H.: A membranebound activity catalysing phosphatidylinositol breakdown to 1,2-diacylglycerol, D-myoinositol 1:2-cyclic phosphate and D-myoinositol 1 -phosphate. Biochem. J. 131, 433-442 (1973)

28) Irvine, R.F. and Dawson, M.C.: The distribution of calcium-dependent phosphatidylinositolspecific phosphodiesterase in rat brain. J. Neurochem. 31, 1427-1434 (1978)

29) Doherty, E.J. and Rowe, C.E.: The intracellular localization of $\mathrm{Ca}^{+}$-stimulated phospholipase $A_{1}$ in rat brain. Brain Res. 197, 113 $122(1980)$ 